\title{
THE CULTURE OF BELIEF AND THE POLITICS OF RELIGION
}

\author{
WILLIAM P. MARSHALL*
}

\section{INTRODUCTION}

Religion has stood at the center of the American stage during the years of the Clinton presidency. The Congress passed, and the President signed, the Religious Freedom Restoration Act ("RFRA") - the most dramatic and extensive piece of legislation addressing freedom of religion issues in our nation's history. ${ }^{2}$ In a dramatic upset, the Republican Party took over Congress in 1994, fueled in large part by the mobilization of Christian conservatives. ${ }^{3}$ The House of Representatives voted on a prayer-in-the-schools amendment for the first time in almost thirty years. ${ }^{4}$ Governments began experimenting with providing social services through faith-based organizations because of dissatisfaction with the success rate of secular-based efforts. ${ }^{5}$ Instances of school violence that had captured national attention were ascribed by some to have been caused by the absence of religion from public education. ${ }^{6}$ Religiously defined hate groups and militias proliferated. ${ }^{7}$ The most controversial and

Copyright (C) 2000 by William P. Marshall

This comment is also available at http://www.law.duke.edu/journals/63LCPMarshall.

* Professor of Law, University of North Carolina (effective January 2001).

The author would like to thank Melvyn Durchslag and Joan Englund for their helpful comments on an earlier draft. Research assistance was provided by Lindsey Carr and Brad Winter. The author served in the Office of the White House Counsel during the Clinton Administration. The opinions expressed herein, however, are solely those of the author and are not those of the Administration.

1. Religious Freedom Restoration Act of 1993, Pub. L. No. 103-141, 107 Stat. 1488 (codified at 42 U.S.C. $§ 2000 b b$ (1994)). The Supreme Court subsequently invalidated RFRA's application to the states on federalism grounds. See City of Boerne v. Flores, 521 U.S. 507 (1997).

2. The only other legislation that even compares with the protections provided to religion by RFRA are the provisions of the Civil Rights Acts, which protect individuals from discrimination on account of religion. Civil Rights Act of 1964, 42 U.S.C. $§ 2000$ (1994).

3. See David S. Broder, A Historic Republican Triumph: GOP Captures Congress, WASH. Post, Nov. 9, 1994, at A1.

4. The amendment did not garner the necessary two-thirds majority to pass the House, but it did capture a numerical majority. See infra text accompanying note 89.

5. See, e.g., Albert R. Hunt, Faith Based Efforts: The Promise and the Limitations, WALl ST. J., Aug. 12, 1999, at A23; Don Lattin, Waging Holy War on Welfare: Unprecedented Partnership Between Religious Charities, Government To Make Reform Work, S. F. CHRON., Sept. 14, 1998, at A1.

6. Patrick Buchanan, for example, was quoted as saying, "You go to Littleton, Colorado, you can see what happens 30 years after the ACLU had its victory and drove God and the Ten Commandments and moral instruction out of America's public schools and brought in psychiatrists and counselors." Anna Cearley, Law Givers: Moses Had Approval, Schools Didn't, SAN DIEGo UnION-TriB., Nov. 19, 1999, at E1.

7. See, e.g., Kevin Sack, Hate Groups in U.S. Are Growing, N.Y. TIMES, Mar. 3, 1998, at A10 
inflammatory law enforcement event of the decade involved the efforts of the federal government to arrest the leader of a religious cult in Waco, Texas. ${ }^{8}$ Congress passed the International Religious Freedom Act, which established the fight against religious persecution as an international relations priority and established an office in the State Department to promote international religious freedom. ${ }^{9}$ The United States intervened in a war in Europe that had been stoked by religious hatred and division..$^{10}$ The list goes on. ${ }^{11}$

Against this background, Professors Randy Lee and Marci Hamilton offer diametrically opposed normative and descriptive assessments of the role of religion in politics. Normatively, Lee believes that in our constitutional system, religion should be an active player in political affairs. ${ }^{12}$ Hamilton contends that the role of religion should be more circumscribed..$^{13}$ Descriptively, Lee believes that religion has been inappropriately marginalized in American political life. ${ }^{14}$ Hamilton asserts that, if anything, religion has been too active a participant in the political scene. ${ }^{15}$ Lee and Hamilton, however, share one common point of agreement. Lee, explicitly, and Hamilton, implicitly, both recognize that religion can be, and often is, a potent political force.

Part II of this comment will address and support the point explicitly offered by Professor Lee-the claim that religion is political. This section will argue, however, that the political manifestation of religion is not confined to the instances when religion becomes involved in express political activity, such as lobbying or partisan politics. Rather, religion must be understood as a pervasive social force that has an inevitable political effect. Part III will address whether religion has been inappropriately marginalized in the public culture. It will show that the purported marginalization is more a matter of perception than reality. While it is true that there is a popular perception that religion has

(noting that according to one study, the number of hate groups, spurned largely by the Internet, increased by $20 \%$ nationwide in 1997); Keith Schneider, Terror in Oklahoma: At a Glance; Right-Wing Movements Around the Country, N.Y. TIMES, Apr. 24, 1995, at B9.

8. See Harrison Rainie et al., The Final Days of David Koresh, U.S. News \& WorLd REP., May 3,1993 , at 24 .

9. 22 U.S.C. $\S \S$ 6401(b), 6411(a) (1998).

10. See, e.g., Chris Burritt, Clinton Vows War on "Hatred," AtlantA J. \& CONST., Jul. 11, 1996, at A1; Chris Hedges, Bosnia's Peace Dividend: Hatred for Everyone, N.Y. TIMES, Jul. 20, 1997, at D3; Not Ethnicity, But Religion, Fuels Balkan Fury, N.Y. TIMES, May 13, 1993, at A22.

11. The legislative and executive actions taken during the Clinton Administration are cataloged in Marci A. Hamilton, Religion and the Law in the Clinton Era: An Anti-Madisonian Legacy, 63 LAW \& CONTEMP. PROBS. 359 (Winter/Spring 2000).

12. See generally G. Randy Lee, When a King Speaks of God; When God Speaks to a King: Faith, Politics, Tax Exempt Status, and the Constitution in the Clinton Administration, 63 LAW \& CONTEMP. PROBS. 391(Winter/Spring 2000).

13. See Hamilton, supra note 11, at 363-64.

14. See Lee, supra note 12, at 392-93.

15. See Hamilton, supra note 11, at 363. Hamilton's and Lee's differing perspectives lead them to two completely different interpretations of the factual record. Lee, for example, views the record of the Clinton Administration as overtly hostile to religion. See Lee, supra note 12, at 392-93. Hamilton, on the other hand, denounces the Clinton Administration's record as being deferential to the point that she describes President Clinton as "the most religiously activist President in history." Hamilton, supra note 11 , at 364 . 
been inappropriately marginalized in American life, the reality is that religion has retained its power as a social and political force. Part III will also attempt to explain the discrepancy between the reality and the perception of the marginalization claim. Part IV will address the normative debate regarding the role of religion and politics, and suggest that there are legitimate reasons why the overt involvement of religion in politics should be treated with some caution. Finally, Part V will use the example of school prayer as an example of why the mix of religion and politics can be harmful to the interests of both politics and religion.

II

\section{RELIGION AS POLITICS}

Religion is a powerful force in the American political scene. Its political role, however, has many guises. Some are explicit, as when churches, religiously affiliated organization, or religious leaders become directly involved in partisan politics or legislative lobbying. Lee's article, for example, recounts the involvement of religion in partisan politics in the 1992 presidential campaign and the 1998 congressional races. ${ }^{16}$ Hamilton's article, in turn, discusses the role of religion in lobbying before Congress. ${ }^{17}$ Yet the instances in which religion becomes explicitly involved in politics, as in these examples, is but the tip of the iceberg. Religion is a pervasively political phenomenon and in understanding this point, it may be helpful to note four different ways religion may present itself as a political force.

First, religion may become involved in expressly partisan activity. This is the example, cited by Lee, of candidates' campaigning from church pulpits and churches promoting candidate selection through literature drops and voting guide distributions at places of worship. $^{18}$ There are other examples. Religiously defined candidates themselves often run on specifically religious agendas. The presidential campaigns of Jesse Jackson, Pat Robertson, and Gary Bauer may be seen as instances of this phenomenon.

Second, religion may assume a prominent role in public policy debates removed from the furtherance of a partisan political agenda. Religion, for example, was deeply involved in the Abolitionist movement before the Civil War. $^{19}$ More recently, in the 1960s, religion was active in promoting racial equality $^{20}$ and in opposing the war in Vietnam. ${ }^{21}$ Currently, among other issues,

16. See Lee, supra note 12 , at 394-97, 410.

17. See, e.g., Hamilton, supra note 11, at 369-71 (discussing the lobbying efforts of the Coalition for the Free Exercise of Religion).

18. See, e.g., Lee, supra note 12, at 395-97.

19. See Gilbert HobBs BARnes, The ANTISLAVERy ImPulse: 1830-1844, at 109-45 (1933).

20. For a discussion of the role of religion in the civil rights movement, see Edward McGlynn Gaffney, Jr., Politics Without Brackets on Religious Convictions: Michael Perry and Bruce Ackerman on Neutrality, 64 TUL. L. REV. 1143, 1165-75 (1990).

21. For an introduction to religious opposition to the Vietnam War, see APRIL CARTER, PEACE Movements: INTERNATIONAL PROTEST AND WORLD POLITICS SinCE 1945, at $92-93$ (1992). 
religion has been active in the pro-life movements ${ }^{22}$ and in efforts to abolish the death penalty. ${ }^{23}$

At times, this public advocacy of specific issues may involve religion in direct lobbying. This is the example, cited by Hamilton, of the Coalition for the Free Exercise of Religion that worked to pass RFRA. ${ }^{24}$ The RFRA example is not unique. Religion has been a lobbying force on a wide range of legislation, from parochial aid and school vouchers to welfare reform and foreign policy.

Third, religion has its political aspects even when it is not explicitly involved in the political controversies of the day. Religion is a system of ideas. As such, it competes with other religions and other ideologies to hold on to its adherents and sway others to its convictions by the power and force of its arguments. ${ }^{25}$ Religion, in short, like other ideologies, is in a constant struggle for the hearts and minds of the citizenry. ${ }^{26}$ This struggle goes beyond the search for converts. Even when religion is not seeking to bring new members into its fold, it, like other systems of ideas, is interested in persuading others as to the merits of its values and beliefs. Such outreach, accordingly, will necessarily affect the broader social and political debate.

Fourth, religion is political even when passive. Religion comprises a part of the social fabric from which political choices are made. Religious beliefs are not insular, and even when not overtly political in themselves, may be potentially laden with profound political overtones. Religious views on the sanctity of life, for example, may deeply affect such matters as animal rights and the environment, as well as such obvious issues as abortion, capital punishment, and physician-assisted suicide. ${ }^{27}$ The role of religion as a political force, in short, is essential and unavoidable. The question to be discussed in the next two sections is how active and pronounced the role of religion should be in the political debate.

22. For a description of the pro-life movement's efforts to ban abortion, see KENNETH L. KARST, LAW'S PROMISE, LAW'S EXPRESSION: VISIONS OF POWER IN THE POLITICS OF RACE, GENDER, AND RELIGION 31, 40-43, 50-57 (1993).

23. See Hanna Rosen, Catholic, Jewish Leaders Target Death Penalty in National Effort, WASH. PosT, Dec. 6, 1999, at A20.

24. See Hamilton, supra note 11 , at 369.

25. See Donald A. Giannella, Religious Liberty, Nonestablishment, and Doctrinal Development, Part II: The Nonestablishment Principle, 81 HARV. L. REV. 513, 517 (1968).

26. People's attachment to religion would seem to bear this out. One study reports, for example, that at least $50 \%$ of people in America do not die in the religion in which they were born. See Mary Rourke, Redefining Religion in America, L.A. TIMES, June 21, 1998, at A1. Presumably, this statistic might be explained, in part, by the relatively slight movement in religious belief that occurs when an adherent changes allegiance among the various sects of Protestantism. Even so, this statistic supports the conclusion that religious beliefs, like political beliefs, are fluid and changeable.

27. See Kent Greenawalt, The Limits of Rationality and the Place of Religious Conviction: Protecting Animals and the Environment, 27 WM. \& MARY L. REV. 1011 (1985-86). 
III

\section{THE PURPORTED MARGINALIZATION OF RELIGION}

As Professor Hamilton notes, Stephen Carter's book The Culture of Disbelief $^{8}$ has been of profound influence in the years of the Clinton presidency. ${ }^{29}$ Professor Carter's thesis is that religion has been inappropriately marginalized by a secular culture and that American democracy and discourse would be better served if religion were a more open participant in the American debate. $^{30}$

This section responds to the marginalization claim. The first question posed is whether the account that religion has been marginalized is accurate. The second is that if the marginalization account is not accurate, what explains its vitality?

There is statistical evidence that supports the marginalization thesis. In 1957, only fourteen percent of Americans believed religion was losing its influence on society. ${ }^{31}$ In 1993, the year the Culture of Disbelief was published, that figure stood at sixty-two percent. ${ }^{32}$

Gleaning too much from this statistic, however, might be a mistake. As indicated in Table 1, the volatility in public opinion on this question has been significant. In 1981, for example, forty-six percent of Americans believed religion was losing influence. Yet, two years later, in 1983, only twenty-two percent held that view. One year later, in 1984, the figure again escalated to thirty-nine percent. Given this volatility, the extent to which these statistics measure actual marginalization, as opposed to some other phenomenon, may be in doubt. ${ }^{33}$

28. Stephen L. Carter, The Culture of Disbelief: How American Law and Politics TRIVIALIZE RELIGIOUS DEVOTION (1993).

29. See Hamilton, supra note 11, at 364-65.

30. Professor Carter is not alone in the academy in asserting that religion has been inappropriately marginalized. For an excellent account, and refutation, of the marginalization thesis, see Theodore Y. Blumoff, The New Religionists' Newest Social Gospel: On the Rhetoric and Reality of Religions' “Marginalization” in Public Life, 51 U. MiAMI L. REV. 1 (1996).

31. See George H. Gallup, Jr., Religion in America: Will the Vitality of Churches BE THE Surprise of the NEXT CENTURY? 54 (PRINCETON RELIGION RESEARCH CENTER, 1996) [hereinafter PRINCETON STUDY].

32. Correspondingly, in 1957, 69\% believed religion had increasing influence on American society, while in 1993 only $27 \%$ held that view. See id.

33. See infra text accompanying notes 61-62 for a partial explanation of the volatility. 
TABLE 1

RELIGION'S IMPACT ON AMERICAN LIFE

\begin{tabular}{ccc}
\hline Year & $\begin{array}{c}\text { Increasing } \\
\text { Influence } \\
\text { (percentage) }\end{array}$ & $\begin{array}{c}\text { Losing } \\
\text { Influence } \\
\text { (percentage) }\end{array}$ \\
\hline 1995 & 37 & 57 \\
1994 & 27 & 68 \\
1993 & 27 & 62 \\
1992 & 27 & 63 \\
1991 & 36 & 55 \\
1990 & 33 & 48 \\
1989 & 33 & 49 \\
1988 & 36 & 49 \\
1986 & 48 & 39 \\
1985 & 49 & 39 \\
1984 & 42 & 39 \\
1983 & 44 & 22 \\
1981 & 38 & 46 \\
1980 & 35 & 46 \\
1978 & 37 & 48 \\
1977 & 36 & 45 \\
1976 & 44 & 45 \\
1975 & 39 & 51 \\
1974 & 31 & 56 \\
1970 & 14 & 75 \\
1969 & 14 & 70 \\
1968 & 18 & 67 \\
1967 & 23 & 57 \\
1965 & 33 & 45 \\
1962 & 45 & 14 \\
1957 & 69 & A \\
\hline
\end{tabular}

Source: George H. Gallup, JR., Religion in America: Will the Vitality of Churches be the Surprise of the NeXt Century? (Princeton Religion Research Center, 1996).

Perhaps more telling in the marginalization debate has been the pervasive and persistent strength of religion in U.S. culture. By all accounts, religion in the United States is thriving. ${ }^{34}$ The statistical evidence is significant. Unlike the

34. See, e.g., A. JAmes Reichley, Religion in American Public Life (1985); Stephen J. Stein, Religion/Religions in the United States: Changing Perspectives and Prospects, 75 IND. L. J. 37 (2000) (discussing the flourishing of diverse religious traditions in the United States). 
polling on the perceived influence of religion on American life, the polling on the influence religion actually has on individual lives of Americans has remained constant-and constantly high. As such, the statistics paint a picture which indicates that the state of religion in the United States is extraordinarily robust. ${ }^{35}$

Belief in God, for example, remains stratospheric. In 1944, ninety-six percent of the American people attested that they believed in God. ${ }^{36}$ Fifty years later, in 1994, the figure was exactly the same. ${ }^{37}$ There were no significant fluctuations in this statistic during this fifty-year period. The high was ninetynine percent (1954), and the low was ninety-four percent (1947 and 1967). ${ }^{38}$

Church membership also has remained high. In 1995, church membership in the United States stood at a rate of sixty-nine percent, at only a slight decline since 1937 when the rate stood at seventy-three percent. ${ }^{39}$ In fact, the range of church membership from 1937 to the present has remained remarkably stable, having a high of seventy-six percent (1943 and 1977) and a low of sixty-five percent (1988 and 1990) during this sixty-year period. ${ }^{40}$

Church attendance also has been notably constant in the last sixty years. In 1939, for example, forty-one percent of the American public stated they attended a church of worship within the last seventy days, compared with fortythree percent in 1995. ${ }^{41}$ Again the level has remained constant during the sixtyyear period, with a high in church attendance of forty-nine percent (1955 and 1958), and a low of thirty-seven percent (1940)..$^{42}$

The vitality of religion in America also may be demonstrated by comparing its strength with that of other countries, including those with established churches. Again, the evidence is compelling. The United States remains one of the most religious countries in the world. ${ }^{43}$ It ranks second only to South Africa on the question of whether God is of major importance in people's lives. ${ }^{44}$ On a one to ten scale, Americans average 8.2. The figure in England, by comparison,

35. The Princeton Study offers an index of religion in America which suggests that the state of religion in America may have been at inordinately low levels at around the time of the publication of Carter's book. The index, however, includes a factor addressing public confidence in organized religion, a factor which, as the study points out, was harmed in the 1980 s by the televangelist scandals. See PRINCETON STUDY, supra note 31, at 16.

36. See id. at 50.

37. See id. at 22.

38. See Princeton Religion Research Center., Religion in America 20 (1986). The 1986 report shows the high of $99 \%$ in 1952, and the $94 \%$ low in 1947, 1975, and 1976.

39. See PRINCETON STUDY, supra note 31, at 41.

40. See id. Interestingly, in comparison, church membership in the late 18 th century stood at $17 \%$. See Roger Finke \& RODNEy STARK, THe CHURChing OF AMERICA, 1776-1990: WinNERS AND LOSERS IN OUR RELIGIOUS ECONOMY 15 (1992). The 17\% figure, however, is quite obviously due in part to the lack of density in population, but it still suggests that organized religion may not have had the pervasive hold on the populace that it enjoys today.

41. See id. at 29.

42. See id.

43. See REICHLEY, supra note 34, at 2 .

44. See PRINCETON STUDY, supra note 31, at 50. 
is 5.7. In France, it is 4.7. ${ }^{45}$ Indeed in 1995, fifty-eight percent of Americans stated that religion was "very important" in their own lives and a full ninety percent described religion as being either "very important" or "fairly important." ${ }^{46}$

The lesson from these studies seems clear. The claim that religion is a marginalized force in American society is not descriptively accurate. ${ }^{47}$

Why then is there the perception that religion has been marginalized? A number of reasons are possible. The first is mass culture-television, cinema, and popular music ${ }^{48}$-in which the presence of religion and religious values have not been especially noticeable. ${ }^{49}$ The second is the well-publicized, overenforcement of anti-establishment norms that occasionally has occurred in settings such as the public schools. Relying incorrectly on the school-prayer decisions, ${ }^{50}$ school officials have prevented students from pursuing clearly permissible activities, such as reading the Bible on buses or in study halls, and the ensuing controversies from these instances have led to a significant counterreaction. ${ }^{51}$ Third, the perception of the marginalization of religion also may have been caused by counter-reactions to the efforts of some ardent separationists who have pursued an antiseptic notion of church and state that would require all aspects of religion to be excised from government. Lawsuits, for example, have been filed to seek removal of everything in government that is religiously laden, from nativity $\operatorname{scenes}^{52}$ to city seals with religious inscriptions $^{53}$ to state mottos that mention God $^{54}$ to prayers at football games ${ }^{55}$ to

45. See id.

46. Id. at 53 .

47. There has been some decline since the 1950s in those who suggest that religion has relevance to their personal existence. According to the Gallup report, in 1957, the figure was $81 \%$. From 1974 through 1995, on the other hand, that amount ranged between 56 and $65 \%$. The study did not offer any data on this issue from the 1960s. See id. at 54.

48. I am indebted to Professor David Barron for his suggestion on this point.

49. Until recently, for example, religion was a subject that was seldom addressed in the broadcast media.

50. See School Dist. of Abington Township v. Schempp, 374 U.S. 203 (1963); Engel v. Vitale, 370 U.S. 421 (1962).

51. See Molly Ivins, Tales of Persecution of Christians Take on Biblical Proportions, Fresno BEE, June 10, 1998, at B5.

52. See, e.g., County of Allegheny v. ACLU, Greater Pittsburgh Chapter, 492 U.S. 573 (1989); Lynch v. Donnelly, 465 U.S. 668 (1984).

53. See, e.g., Webb v. City of Republic, 55 F. Supp. 2d 994 (W.D. Mo. 1999) (determining the fish on city's seal was a religious symbol and thus violated the Establishment Clause); ACLU v. City of Stow, 29 F. Supp. 2d 845 (N.D. Ohio 1998) (finding the Christian cross contained in the city's seal violated the First Amendment.); Saladin v. City of Milledgeville, 812 F.2d 687 (11th Cir. 1987) (holding that individual citizens did have standing to bring a challenge to the word "Christianity" on the city's seal-the city settled out of court).

54. See ACLU v. Capitol Square Review \& Advisory Board, 20 F. Supp. 2d 1176 (S.D. Ohio 1998) (finding that the state motto of Ohio, "With God All Things Are Possible," was not offensive to the Establishment Clause as the motto did not impermissibly favor religion generally).

55. See, e.g., Jager v. Douglas County School Dist., 862 F.2d 824 (11th Cir.) (football game invocations), cert. denied, 490 U.S. 1090 (1989); Doe v. Santa Fe Indep. Sch. Dist., 168 F.3d 806 (5th Cir.), cert. granted, 120 S. Ct. 494 (U.S. Nov. 15, 1999) (No. 99-62) (granting a petition for a writ of certiorari only as to student-led, student-initiated prayer at football games). 
Christmas pageants. ${ }^{56}$ Such suits have been filed despite the knowledge that the lawsuits themselves often may be politically divisive and antagonistic. ${ }^{57}$ Fourth, in a point directly addressed by Stephen Carter, ${ }^{58}$ some prominent voices in the educational elite have staunchly, and in my opinion wrongly, argued that religious views should be held in second-class status relative to views derived from so-called reason. ${ }^{59}$ Again, the marginalization claim may be seen as a counter-reaction to those efforts. ${ }^{60}$

The most potent force behind the misperception that religion is marginalized in American society, however, may be political. Religiously oriented political groups and movements, quite simply, have been active in spreading the marginalization message for their own political benefit. ${ }^{61}$ The political explanation makes sense. Contending that the political culture is in the control of a purported secular elite interested in demeaning religion is simply effective politics-particularly if one can associate the positions of this secular elite with issues one is campaigning against. The so-called "pro-religionists" can appeal to the vast majority who believe in God and religion by claiming that this majority is being belittled and marginalized by a hypothetical secular establishment. Undoubtedly this is an effective ploy-even if it is not based on fact. And factually based it is not. As Michael Kinsley stated in his review of Carter's book, "[d]oes anybody really think it is harder to stand up in public ... and say, 'I believe in God,' than it is to stand up and say, 'I don't'?"

IV

\section{RELIGION AND POLITICS}

The role of religion in politics has received an enormous amount of scholarly attention, ${ }^{63}$ and it is not the purpose of this comment to review that literature. Some observations may be in order, however. The conclusion that religion is politics would seem to argue strongly that religion, as a political

56. See Florey v. Sioux Falls Sch. Dist., 619 F.2d 1311 (8th Cir. 1980).

57. See Lynch, 465 U.S. at 700 (Brennan, J., dissenting) (noting the divisiveness that the debate over the crèche caused).

58. See CARTER, supra note 28, at 55.

59. For an excellent attack on those who suggest religion is based upon an epistemologically inferior mode of thought than is reason, see Frederick Mark Gedicks, Public Life and Hostility to Religion, 78 VA. L. REV. 671 (1992). Gedicks criticized Bruce Ackerman who wrote that "the liberal belief that reason mediates political conflict is no less a matter of faith than religious beliefs in God." See id. at 695 (quoting BRUCE ACKERMAN, SOCIAL JUSTICE IN THE LiBERAL STATE (1980)).

60. See CARTER, supra note 28, at 271-74.

61. The Princeton Study suggests that the volatility of public opinion on the marginalization issue may indicate that movements and headlines may affect public perception. See PRINCETON STUDY, supra note 31, at 54 .

62. Michael Kinsley, Stephen L. Carter's The Culture of Disbelief: How American Law and Politics Trivialize Religious Devotion, NEW REPUBLIC, Sept. 13, 1993, at 4 (book review).

63. See generally Kent Greenawalt, Religious Convictions And Political Choice (1988); Michael J. Perry, Love And Power: The Role of Religion And Morality In AMERICAN POLITICS (1991); Symposium, The Role of Religion in Public Debate in a Liberal Society, 30 SAN DIEGO L. REV. 643 (1993). 
force, should be whole-heartedly welcomed into the political debate. After all, excluding religion from the public square ${ }^{64}$ would seem to violate central First Amendment-Speech Clause-values, including the promotion of truth, ${ }^{65}$ selfgovernance, ${ }^{66}$ and the equality of ideas. ${ }^{67}$ Moreover, this call for religious inclusion would be appropriate even if religion were not marginalized.

Nevertheless, before proclaiming the value of direct religious involvement in the political process as an unmitigated benefit, as Professor Lee would have us do, it is worth noting some of the countervailing considerations inherent in that approach. Religion may have a place in the political debate, but this does not mean its presence is always salutary.

Professor Hamilton is correct when she maintains that religion is not an "undifferentiated force for good." ${ }^{68}$ Religion has a dark side of intolerance, persecution, and divisiveness. ${ }^{69}$ The Framers understood this. ${ }^{70}$ They were well acquainted with the European history of religious wars and religious persecutions. $^{71}$ This dark side of religion has not ebbed. Religious wars and persecutions are still endemic worldwide. Meanwhile, in the United States, as Hamilton notes, virulent religious cults exist that are blatantly racist, antiSemitic, anti-Catholic, and violent. ${ }^{72}$

Nor is the dark side of religion likely to fade. Rather, its existence is a quite understandable by-product of the nature of religious belief. Strong belief often leads to intolerance-an observation Justice Holmes offered in Abrams $v$. United States: $:^{73}$ "If you have no doubt of your premises or your power and want a certain result with all your heart you naturally express your wishes in law and sweep away all opposition." ${ }^{\text {"74 }}$ Religious belief also may be especially troublesome from this perspective because it addresses humanity's greatest

64. The term "public square" is from Richard J. NEUHAus, ThE NAKED PubliC SQUARE: RELIGION AND DEMOCRACY IN AMERICA (1984). Neuhaus, like Carter, argues that efforts to circumscribe religion's role in political debate improperly diminish religion's role in society and impoverish public discourse.

65. See Abrams v. United States, 250 U.S. 616, 630 (1919) (Holmes, J., dissenting).

66. See generally AleXANDER Meiklejohn, Free SPEech AND its Relation to SelfGOVERNMENT (1948).

67. See Kenneth Karst, Equality as a Central Principle in the First Amendment, 43 U. CHI. L. REV. 20 (1975); see also Geoffrey R. Stone, Content Regulation and the First Amendment, 25 WM. \& MARY L. REV. 189 (1983).

68. Hamilton, supra note 11 , at 361 .

69. See generally William P. Marshall, The Other Side of Religion, 44 Hastings L.J. 843 (1993).

70. The views of James Madison, for example, are discussed in Hamilton, supra note 11, at _.

71. As Thomas Jefferson wrote in a letter to Reverend Thomas Whittemore:

I have never permitted myself to meditate a specific creed. These formulas have been the bane and ruin of the Christian church, which, through so many ages, made of Christendom a slaughter-house and at this day divides it into castes of inextinguishable hatred to one another.

15 THE WRITINGS OF THOMAS JEFFERSON 373-74 (Albert Ellery Bergh ed., 1903).

72. See Hamilton, supra note 11, at 368 (criticizing President Clinton's "frequent references to the spirituality of the American people without reference to the white supremacist or other hate groups that operate on plainly religious, though socially unacceptable, premises").

73. 250 U.S. 616 (1919).

74. Id. at 630 (Holmes, J., dissenting). 
fears and, accordingly, may promote particularly strong attachments, and an accordant antipathy, toward those who would bring those beliefs into question in a manner that might re-excite this underlying fear. ${ }^{75}$

Second, religion not only is not an "undifferentiated good"; it also is not undifferentiated. Religion is not a monolithic phenomenon: In support of this point, it is useful to return to Lee's understanding. Religion, as he notes, is political: It seeks to attract converts and adherents. Religious sects are thus in competition with one another. To treat religion as a unified phenomenon ignores this reality and makes light of the extent of the division among sects and denominations. It also minimizes the upheaval that results when religion becomes explicitly involved in politics, particularly when religion becomes politically active along specifically religious lines.

One only need look to history to support this claim. Debates over parochial aid and education divided Catholics and Protestants in this country for decades. $^{76}$ Divides over which version of the Ten Commandments should receive government sanction caused riots and death in Philadelphia in the early nineteenth century and continue to raise acrimony and division today. ${ }^{77}$ Indeed, even when religion is able to act ecumenically in politics, there are always dangers of subsequent division along religious lines. The Coalition for the Free Exercise of Religion that worked to pass RFRA, for example, may be fraying along religious lines in their efforts to get follow-up legislation, known as the Religious Liberty Protection Act ("RLPA"), passed. This is because of religious differences over whether RLPA should protect landlords from open housing legislation, which would otherwise force the landlords to rent to gays or unmarried couples, in violation of the landlords' religious beliefs. ${ }^{78}$ The specter of religious groups battling along these lines is disconcerting. As Ira Lupu explains, "[t]hese are not the sort of battles for which ordinary politics are wellsuited; they cannot be readily compromised, should not be resolved on the basis of political strength, and encourage rather than soften sectarian animosities."

Professor Hamilton's essential point then is well taken. Caution should be exercised before too warmly welcoming religion into the public square. On the other hand, Hamilton's position should not be taken too far. That caution should be exercised does not mean that all exclusions of religion from the legislative process and from public debate are advisable or that all attempts to legislate on matters affecting religion are ill-advised. Religion historically has made significant contributions to the political debate, and many of the current

75. This point is more fully developed in William P. Marshall, The Other Side of Religion, 44 HASTINGS L.J. 843 (1993).

76. For a more thorough examination of the hostility between Roman Catholics and mainstream Protestants over aid to parochial schools, see WiLLIAM G. Ross, Forging NEW FREEDOMS: NATIVISM, EDUCATION AND THE CONSTITUTION 1917-1927, at 23-25, 70-73 (1994).

77. See J. William Frost, A Perfect Freedom: Religious Liberty in PenNSylvania 156 (1990); E.J. Dionne, Jr., Bridging the Church-State Divide, WASH. Post WeEKLY, Oct. 11, 1999, at B1.

78. See Ira Lupu, The Case Against Legislative Codification of Religious Liberty, 21 CARDOZO L. REV. 565, 583 (1999).

79. Id. at 584 . 
religious initiatives Hamilton catalogues are not simply examples of the unrestrained execution of religion's political force. The guidelines on expression in the public schools ${ }^{80}$ and the Guidelines on Religious Exercise and Religious Expression in the Federal Workplace ${ }^{81}$ that Hamilton criticizes, for example, are more restatements of the law, intended to eliminate religious divisiveness and misunderstandings, than they are provisions that create new religious rights or promote religious favoritism.

However, rather than quibbling with any of the specific measures Hamilton addresses, it is worth focusing on the most prominent proposal regarding religion offered in the 1990s - the school-prayer amendment. After all, unlike the Religious Freedom Restoration Act, the federal workplace guidelines, and virtually every other measure cited in Hamilton's article, the proposed schoolprayer amendment was the only provision during the Clinton presidency to capture the popular imagination and the attention of the media. For this reason, the school-prayer amendment may provide the most accurate insight into the merits of the normative and descriptive accounts of religion and politics offered by Professors Hamilton and Lee.

\section{$\mathrm{V}$ \\ POLITICS AND SCHOOL PRAYER}

The school-prayer amendment, commonly known as the "Istook Amendment," read as follows:

To secure the people's right to acknowledge God according to the dictates of conscience: Neither the United States nor any State shall establish any official religion, but the people's right to pray and recognize their religious beliefs, heritage, or traditions on public property, including schools, shall not be infringed. Neither the United States nor any State shall require any person to join in prayer or other religious activity, prescribe school prayers, discriminate against religion, or deny equal access to a benefit on account of religion. ${ }^{82}$

The amendment could have been easy to pass. The Supreme Court decisions invalidating school prayer, ${ }^{83}$ upon which the proposed amendment was based, have never been widely accepted. ${ }^{84}$ Support for the amendment was based on a classic use of the marginalization claim: that religion has been unduly marginalized in the United States. ${ }^{85}$ Proponents of the amendment framed the debate in terms of a religious citizenry versus secular elitists. ${ }^{86}$

80. See U.S. DeP'T. OF Educ., Public Schools ANd Religious Communities: A First AMENDMENT GUIDE (1999).

81. 33 WEEKLY COMP. PRES. DOC. 1246-48 (Aug. 14, 1997).

82. H.R.J. Res. 78, 105th Cong. (1998).

83. See Engel v. Vitale, 370 U.S. 421 (1962); School Dist. of Abington Township v. Schempp, 374 U.S. 203 (1963).

84. See infra text accompanying notes $87-88$.

85. See supra text accompanying notes $28-62$.

86. According to Representative Merrill Cook,

on a national level, teacher unions are decrying a return to conservative values and, in particular, personal religious expression. They say those values and those religious 
School prayer had strong and longstanding popular support. In 1995, seventyone percent of the American people supported school prayer, while only twenty-five percent opposed it. ${ }^{87}$ This support was also constant. In 1984, for example, sixty-nine percent favored an amendment, while twenty-four percent opposed. In 1974, seventy-seven percent favored an amendment, while only seventeen percent opposed. ${ }^{88}$

Nevertheless, although the amendment garnered a numerical majority, it did not receive enough votes for passage. ${ }^{89}$ That it did not pass may be testament to the fact that the dangers of sectarian politics and religious divisiveness have not been forgotten. This is because underlying the issue of school prayer is the issue of whose prayer-an issue of enormous stakes to religious communities given the value of government imprimatur and the reality that for some religious traditions, being exposed to another tradition's prayer is a sin.

Accordingly, the issue of whose prayer, if left to resolution through the political processes, would invariably lead to sectarian politics of the worst kind. Consider the political climate that would be created when competing religious factions contend that their prayer should become the school standard or, perhaps more dangerously, when an alliance of factions assert that the schools should be permitted to offer a variety of prayers except for those of unpopular sects and denominations. Such a political fight could lead both to the establishment of the political dominance of particular religious factions and to the subordination of others. It also may lead to the full-scale abandonment of public education by religious groups opposed to the political majority's choice of prayer. ${ }^{90}$

The passage of a school-prayer amendment, accordingly, would have created a climate of sectarian division that itself was "one of the principle evils against which the First Amendment was intended to protect." ${ }^{\text {"1 }}$ It also would have proved the theses of both Professors Lee and Hamilton. It would have shown that religion is indeed political, as Professor Lee has argued. It would have established that the politics of religion is incomparably dangerous, as Professor Hamilton has warned.

expressions are a threat to public schools. Why? Because they are liberals, and they are out of touch with 80 percent of the people of my State and indeed this country, who believe that we should get violence out of our schools and allow into our schools personal religious expression.

144 Cong. Rec. H4078 (daily ed. June 4, 1998) (statement of Rep. Cook).

87. See PRINCETON STUDY, supra note 31 , at 75.

88. See id.

89. The House failed to pass H.R.J. Res. 78 by a recorded vote of 224 ayes to 203 noes (with twothirds required for passage). Another 61 votes in favor would have been required to amend the Constitution. See H.R.J. Res. 78, 105th Cong. (1998), 144 CONG. REC. H4078 (daily ed. June 4, 1998).

90. See Lemon v. Kurtzman, 403 U.S. 602, 627 (1971) (Douglas, J., concurring). The fact that school prayer in the United States had been traditionally Protestant is what initially motivated the Catholics to establish parochial schools.

91. See id. at 622 . 